Linguistik Terapan 16 (3) (2019): 543 - 551

Jurnal Linguistik Terapan Pascasarjana

Available online

http://jurnal.unimed.ac.id/2019/index.php/JLT-Unimed

\title{
THE ABILITY OF LANGUAGE SKILLS OF AN AUTISTIC STUDENT: A Case Study by 7 Year Autistic Student
}

\author{
Romaida Lubis \\ Rahmad Husein \\ Sumarsih \\ English Applied Linguistics Program \\ Postgraduate Program - Universitas Negeri Medan
}

Diterima September 2019; Disetujui Oktober 2019; Dipublikasikan Desember 2019

\section{ABSTRACT}

This research aims to describe the ability of active/expresive language and passive/ reseptive language of an autistic student and the effort to improve the language itself helped by the teacher and the shadow teacher in a non-govermental school in Medan. This research uses qualitative descriptive with study case of an autistic student in primary second grader, his initial is FR. Technique of data collection are observation, interview, and documentation. Technique of data analysis are data condensation, data display and verification and conclusion. The result of research showed that the ability of active/expressive language of FR still had difficulties in pronouncing, unclear articulation for certain letter such as $\mathrm{r}$, n, ny, l, talk simple, unable to have interaction and communication properly, unable to convey the information, requesting what he needed use incomplete sentence when he got depresion, he needed help in writing. And the ability of passive/ receptive FR still have difficulties to comprehend the sentence he heard, able to understand simple sentence only based on his daily experience, able to answer simple sentence when the question asked is same with the statement, respond the long questions by replying the last sentence only, unable to comprehend the reading.

Keyword: Active/expressive, passive/receptive, autistic

How to Cite: Lubis, Romaida (2019).

The Ability of Language Skills of An Autistic Student : A Case Study by 7 Year Autistic Student. Jurnal Linguistik Terapan Pascasarjana Unimed, 16 (3): 543 - 551

$$
\text { *Corresponding author: }
$$

ISSN 0216-5139

lubis.romaida@yahoo.com 


\section{INTRODUCTION}

Most students with Autism Spectrum Disorder (ASD) are difficult to write and read. Even a simple writing assignment can trigger a major meltdown. Education is one of the human rights which is the most fundamentally protected and guaranteed by various international and national legal instruments (Sunaryo, 2009:1). The opportunities to get quality education for all, regardless of race, skin color or cultural diversity, all without discrimination. Children with special needs have the same rights to follow formal education. One form of formal education for children with special needs is inclusive education. Based on Staub and Peck, inclusive education is the placement of children with special needs at low, middle and high levels in full in the regular class (http://pokjainklusifkalsel.org). Children with special needs that is allowed to school in inclusive school is autistic student (http://www.autis.info). An inclusive strategy must focus on the interaction between students and their environment. Therefore, the attitude of discrimination in the implementation of inclusive education can be eliminated through social interaction that exist between students with autism with other regular students.

Classroom and school environment at inclusive school are tailored to be able to provide a sense of pleasure, acceptance, friendly, caring, loving, appreciating, living and learning in togetherness. So, communication and social interaction will be established well between students with autism and all school members. A child with autism usually experienced developmental disorder which causes delays in lamguage skills, socialize, and experience communication problems. Therefore, language and communication skills are indeed needed by autistic children to interact and socialize naturally with other normal children in inclusive schools. Integrating special needs students in a regular classroom is rooted from several reasons (Rutte, 2014). The special needs stdents and teachers feel that they have been excluded and hidden away in tgeir school, even the best equipped school can 
not replace the normal environment. Integrating students is also considered to be more attractive to parents. The development of character values like tollerance, emphaty, and helpfulness is often not a priority in mainstream schools and a policy of integration could help improve this. Inclusion is also pertaining to equity and social justice which show acceptance, and practice respect, empathy, care and recognition (Frattura \& Capper, 2007; Theoharries, 2009; Ford, 2013).

How to improve language skills for children with autism is can be obtained through inclusive schools. Sekolah HS Medan is one of the non-governmental school in Medan located in Padang Bulan which accept the children with special needs in regular class. There is one student with special need for each classroom, and each special need students must be supervised by the shadow teacher. The school educational approach emphasizes active participatory learning. Active learning means students have direct, hands-on experiences with people, objects, events, and ideas. Children's interests and choices are at the heart of HS school program. They construct teir own knowledge through interactions with the world and the people around them. HS school use the term scaffolding to describe the process whereby adults supports and gently extend children's thinking and reasoning.

Based on the interview result from the shadow teacher, FR joined the school curriculum when he was 6 year old with limited vocabulary and the word that he can say is "what" to talk to others, express their desires, and ask for something. In addition, his writing ability is limited only to copy letters, and he does not have reading ability and he does not have eye contact when listening or being invited to speak to others and these becomes a barrier for children to interact and follow the learning process. The research aims to describe the ability of active/expressive language and passive/receptive language of an autistc student in HS school. Theoritically, this research can enhance the knowledge in inclusive education 
in Elementary school, especially regarding to the ability of active/expressive language and passive/receptive language of autistic students in elementary inclusive school.

\section{THEORETICAL REVIEW}

\subsection{Features of Autism}

Autism is a disorder that is present from birth or very early in development that affects essential human behaviors such as social interaction, the ability to communicate ideas and feelings, imagination, and the establishment of relationships with others. It generally has life-long effects on how children learn to be social beings, to take care of themselves, and to participate in the community. Autism is a developmental disorder of neurobiological origin that is defined on the basis of behavioral and developmental features. Although precise neurobiological mechanisms have not yet been established, it is clear that autism reflects the operation of factors in the developing brain. As yet, known direct links between pathophysiology and behavior in autism are still rare and have not yet had great influence on treatments or diagnoses (Rumsey et al., 2000).

\subsection{The Challenge of Educating Children with Autism}

Education, both directly of children, and of parents and teachers, is currently the primary form of treatment in autism. For the purposes of this report, education is defined as the fostering of acquisition of skills or knowledge - including not only academic learning, but also socialization, adaptive skills, language and communication, and reduction of behavior problems - to assist a child to develop independence and personal responsibility. Education includes services that foster acquisition of skills and knowledge, offered by public and private schools; infant, toddler, preschool and early education programs; and other public and private service providers. 


\section{RESEARCH METHODOLOGY}

\subsection{Data and Source of Data}

According to Bogdan and Biklen (1992:106), the data refers to the rough material researchers collect from the world they are studying; they are the particulars that from the basis of analysis. The data in this investigation, the source of data was taken from one autistic student. This student schools in one of non- governmental school in Medan in Grade 2. He was chosen to be researched because he is the student whom the researcher followed his improvement in attitude and behavior. The first time he joined to this school was in grade kindergarten. He was dependent student in whole activity he did, starting from reading, writing, focusing even for eating, toileting, preparing properties for all activities. He spent time at school for 8 hours. After spending 5 years in this school, he showed his improve in academic, even though he could not achieve the target curriculum. The school did not apply the IEP (Individual Education Plan) curriculum for autistic students, even though the school accepts the autistic students. He was an autistic student who always supervised by his shadow teacher. He is the autistic student who likes to read books but not write. He loves to write his own experience rather than subject to be taught in the classroom.

\subsection{Technique of Data collection}

The technique of data analysis of this study was collected by classroom observation, interviewing with an autistic student, and capturing student's writing about everything he wrote in his books. The researcher will do the classroom observation to observe the learning atmosphere during the autistic student learn in this classroom. The factors that affect the student's concentration will be seen during observation.

\subsection{The Instrument of Collecting the Data}

Based on the technique of data used in this research, a tape recorder, notebook, digital camera. The researcher will do the observation in the classroom to see the learning 
atmosphere, learning environment that can affect the student to write using the video. The researcher will do the interview to the student with ASD.

\section{FINDINGS AND DISCUSSION}

\subsection{Findings}

Subject in this research is a student of a non governmental school that based on assessment from an expert at the beginning of school declared as an autistic student. The autistic student is FR. FR is a 7 year old boy and he is in elementary second grader. For the first time, he joined the school, FR could not speak much because he had limited vocabulary. Based on the results of assessment by experts at the beginning of school, FR got difficulty in doing eye contact during interacting with others, showed the signs of autism such as parrot, chatter repeatedly meaningless, hard to concentrate, hyperactive and speech delay. Results of progress reports on learning of FR during in grade 1 reported that RF often played with his hand, legs, parrot, and called the people's name around him. Based on the interview from his previous teacher, he had problem in working with group, problem in communication, and hard to mingle with other friends.

Based on assessment result, interview result, and observation, showed that FR got language disorder in active/expressive (speaking and writing) and passive/receptive language (listening and reading).

\subsubsection{Speaking Ability (Active/Expressive language)}

Based on the observation result, FR could speak maximum 6 words in a sentence, although he seldom to use 6 words in his sentence. He usually only said 1-2 words in his communication. Based on the observation summary, found that the words that contain letter and suffix 1, ny, m, r, ng and words that conrains conconant blend pronounced with unclear articulation. Based on the interview result with his form teacher, it is known that his speaking ability is still limited, and he talked disconnected with unclear articulation. When FR is 
focusing in his communication, he always responds the question given, although he did not understand the question.

\subsubsection{Writing Ability (Active/Expressive language)}

Based on the observation, FR could not write well. But he could write a word or a meaningless sentence based on his daily activity. He also got problem in writing foreign language. In English lesson, he was asked to fill some simple questions, such as arranging some letter into correct word, but he could not complete this task. Based on the data, the researcher concluded that his writing ability was still low. He could write 2-3 words individually in answering the questions helped by the teacher. He still got difficulties to comprehend conconant blend. He always forgot to write capital letter at the beginning of the sentence. He has not been able to create a various sentence such as statement, question, and command. Even, FR got difficulties in writing a sentence individually.

\subsubsection{Listening Skill (Passive/Receptive language)}

Based on the observation, FR could understand the sentence if the sentence is simple and familiar for him. While, FR got difficulties when he listened to the long sentence, and unfamiliar words, he showed his confusing expression. It showed from his simple conversation with his teacher in the classroom.

$$
\begin{aligned}
& \text { Teacher : FR, where did you go for holiday? } \\
& \text { FR : ahh...holiday? }
\end{aligned}
$$

FR did not answer his teacher directly because he did not have holiday everyday, so the word holiday is unfamiliar for him. FR also could not understand the command and instruction if it is long command and instruction. But, he could a bit understand when the command and the instruction is repeated, single, and short command. 


\subsubsection{Reading Skill (Passive/Receptive language)}

Based on the observation, his reading skill is still need to be encouraged. He read disconnected. In English subject, FR read the word based on the writing. It was caused by his unclear articulation when he's reading. Some words with unclear articulation such as besar it's read besa, plant-----plan, desa-----besa, membuat--------membua. Language skill is not only able to read, but must be able to understand what he read. Based on whole observation, FR was not able to understand the sentence he read individually. Some of the reading must be helped by the teacher by describing and questioning. FR could answer the question from the sentence he read if the sentence was written exactly same with the sentence that he ever read before. But sometimes, FR still got trouble to answer the question given and the teacher need to give clue. He answer with 1-2 words. FR understand the sentence if the sentence use familiar word for him and it is a simple sentence.

\subsection{Discussion}

Based on the research toward the autistic student about the ability of active/receptive language such as speaking skill, FR could communicate well with someone else if it is just saying words, although his language is disconnected. FR could pronounce 6 words at the same time, but is really seldom to happen. Regarding to his speaking ability, FR could respond the questions given eventhough he did not understand the question. His speaking skill effects his communication and also interaction with others. FR did not have ability to communicate with others. Listening is an activity that really needs high concentration. FR's concentration is easy to be distracted during studying. He could not have eye contact with someone who is talking with him. Comprehending a reading could be doneby giving question. FR could answer the question if the question is same with the statement. To comprehend a reading, FR could understand the simple reading only related to his daily life. 


\section{CONCLUSION AND SUGGESTION}

Based on the result of the research, concluded that the ability of active/expressive language of FR are still having problem in fluency, ariculation, and pronounciation is not clear in some letters such as $1, \mathrm{t}, \mathrm{m}, \mathrm{r}$, speak with simple words, unable to communicate individually, unable to give information, saying his want when he was got depresion, unable to write independently, unable to make expressive writing. The suggestion for shadow teacher is to make the various and interesting game in encouraging the autistic student to talk more. For the teachers, need to increase the ability of language skills of an autistic student by treating and stimulating them to be more active in the classroom.

\section{REFERENCES}

[1] American Psychiatric Association. (2000). Diagnostic and Statistical Manual of Mental Disorders (4th ed.), (DSM IV-TR). Washington, D.C.

[2] Frattura, E. M., \& Capper, C. A. (2007). Leading For Social Justice: Transforming Schools for All Learners. Thousand Oaks, CA: Corwin.

[3] Hutchinson, T., \& Waters, A. (1991). English for Specific Purposes; A Learning Centered Approach. New York, USA: Press Syndicate of the University of Cambridge.

[4] Sunardi \& Sunaryo. (2007). Intervensi Dini Anak Berkebutuhan Khusus. Jakarta: Departemen Pendidikan Nasional.

[5] Sunaryo. (2009). Manajemen Pendidikan Inklusif (Konsep, Kebijakan, dan Implementasinya dalam Perspektif Pendidikan Luar Biasa). Makalah. Bandung: Jurusan PLB FIP UPI.

[6] Rutte, V. (2014) Integration Models for Elementary and Secondary Schools in Austria. Making It Happen. United Nations Educational, Scientific and Cultural Organization (e-book downloaded on 12/6/2014 at 10.35) 